\section{Variations saisonnières des proportions relatives des acides gras d'un beurre de laiterie d'Ille-et-Vilaine}

par

J. P. GALLACIER, J. P. BARBIER et

S. KUZDZAL-SAVOIE

\section{Note complémentaire (1)}

Il convient d'introduire dans le tableau 3 et en remplacement de la dernière ligne, les limites de variation des proportions relatives des acides gras majeurs du beurre observées aux Pays-Bas (Roos, 1974) et reportées dans le tableau présenté ci-contre :

En outre, un travail récent de Mannaert (1972) permet de compléter les informations relatives aux beurres belges.

\section{Références bibliographiques}

Roos (J. B.) (1974). - Communication personnelle.

MANnAeRT (P.) (1972). - I. Etude de la matière grasse butyrique en Belgique. Région I. Revue de l'Agriculture, $25,1479-1488$.

(1) Cf. "Le Lait ", n 533-534, marsavril 1974, 117-138.

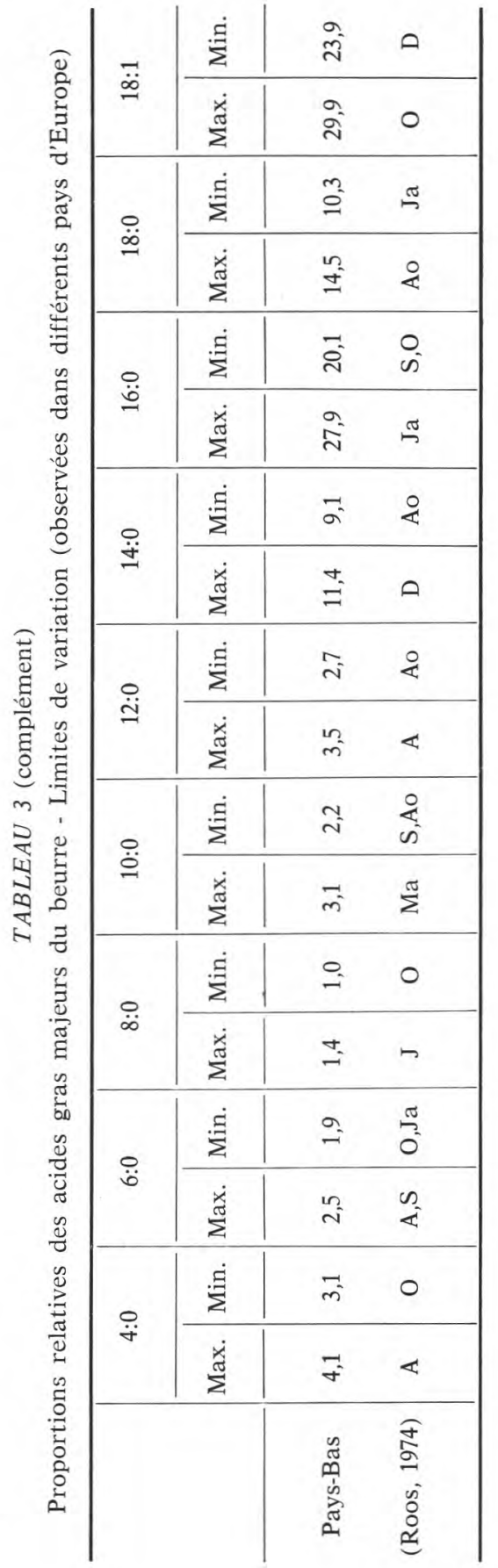

